\title{
Functionalization of sewage sludge char by partial oxidation with molecular oxygen to enhance its adsorptive properties
}

\author{
María Atienza-Martínez a, 1, *, Nurull Nadia Binti Suraini a , Javier Ábrego a , Isabel Fonts ${ }^{\text {a, b }}$, \\ Luisa Lázaro a , Hans-Heinrich Carstensen ${ }^{\mathrm{a}, \mathrm{c}}$, Gloria Gea ${ }^{\mathrm{a}}$ \\ a Thermochemical Processes Group (GPT), Aragon Institute for Engineering Research (I3A), Universidad de Zaragoza, Spain \\ b Área de Química y Medio Ambiente, Centro Universitario de La Defensa (CUD) de Zaragoza- Academia General Militar, 50090, Zaragoza, Spain \\ ${ }^{\mathrm{c}}$ Fundación Agencia Aragonesa para la Investigación y el Desarrollo (ARAID), Zaragoza, Spain
}

\section{A R T I C L E I N F O}

\section{Article history:}

Received 26 June 2020

Received in revised form

11 November 2020

Accepted 14 November 2020

Available online $\mathrm{xxx}$

Handling editor: Prof. Jiri Jaromir Klemeš

\section{Keywords:}

Sewage sludge

Char

Oxygen activation

Oxygenated functional groups

Ammonium adsorption

\begin{abstract}
A B S T R A C T
This study investigates the activation of sewage sludge char through partial oxidation with molecular oxygen with the goal to increase the concentration of oxygen-containing surface functional groups and to enhance its ammonium adsorption capacity. The effects of oxidation temperature $\left(200-350{ }^{\circ} \mathrm{C}\right)$, oxygen concentration (5-21 vol \%) and oxidation time (30-120 $\mathrm{min}$ ) on the degree of char oxidation are analyzed. The results obtained by thermogravimetric and elemental analysis, and Fourier Transform Infrared and X-ray Photoelectron spectroscopy corroborate the incorporation of oxygenated functional groups on the surface of sewage sludge char either at low temperature $\left(200{ }^{\circ} \mathrm{C}\right)$ using air or at higher temperature $\left(350^{\circ} \mathrm{C}\right)$ using $5 \% \mathrm{O}_{2}$ for $30 \mathrm{~min}$. The oxidation of sewage sludge char hardly increases its specific surface area. The operating conditions during oxidation must be carefully controlled to avoid runaway reactions that lead to total oxidation of char. The evolution of $\mathrm{CO}$ and $\mathrm{CO}_{2}$ during oxidation is a good indicator of the advance of the oxidation/burn-off reactions. The ammonium adsorption capacity of sewage sludge char increases after oxidation under mild operating conditions, providing support to the idea of onsite utilization of sewage sludge as ammonium adsorbent in waste water treatment plants. This would provide a step forward towards the implementation of a circular economy.
\end{abstract}

(c) 2020 Elsevier Ltd. All rights reserved.

\section{Introduction}

Anaerobic digestion is one of the most widely used processes for wastewater sludge stabilization in treatment plants with average wastewater flows greater than $20,000 \mathrm{~m}^{3} \mathrm{~d}^{-1}$ (Appels et al., 2011). Apart from biogas, this process generates a by-product denoted as digestate, which is usually subjected to a dewatering procedure. Dewatering produces two streams: a liquid fraction (called digester side stream) and a solid fraction referred to as dewatered sewage sludge (SS). One of the current challenges faced by anaerobic digestion units is to find efficient low costs ways to manage both

\footnotetext{
* Corresponding author.

E-mail addresses: maria.atienza@unavarra.es (M. Atienza-Martínez), aidan_tc@ yahoo.com (N.N. Binti Suraini), javabr@unizar.es (J. Ábrego), isabelfo@unizar.es (I. Fonts), llazaro@unizar.es (L. Lázaro), hcarsten@unizar.es (H.-H. Carstensen), glogea@unizar.es (G. Gea).

1 Grupo de Reactores Químicos y Procesos para la Valorización de Recursos Renovables, Departamento de Ciencias, Edificio de los Acebos, Universidad Pública de Navarra, Campus de Arrosadía, E-31006 Pamplona, Spain.
}

streams. The digester side stream, which contains large amounts of ammonium ions (500-1500 $\mathrm{mg} \mathrm{L}^{-1}$ ), is often recirculated to the wastewater treatment plant header. Ammonium ions $\left(\mathrm{NH}_{4}^{+}\right)$from recirculation may contribute up to $15-20 \%$ of the total amount of ammonium in the inlet stream (Wehrle Umwelt GmbH, 2016). Removal of ammonium increases the overall wastewater treatment costs for energy and chemicals and presents a key challenge to meet regulatory nitrogen discharge limits. High nitrogen concentrations in liquid effluents may lead to the eutrophication of the receiving waters (Estrada et al., 2015) and it is recommended to reduce the $\mathrm{NH}_{4}^{+}$concentration in the digester side stream prior to its recirculation to the header of the wastewater treatment plant. Currently, $\mathrm{NH}_{4}^{+}$is removed from wastewater through biological nitrogen removal technologies, which require rather energy intensive nitrification and denitrification steps (Ma et al., 2016). Also, the removal efficiency of biological nitrogen units is limited by the bacteria growth, which varies with $\mathrm{pH}$ and temperature fluctuations in the digester side stream (Ma et al., 2016).

Among other techniques, adsorption appears to be a promising 
alternative method for $\mathrm{NH}_{4}^{+}$removal due to the ease of operation and simplicity of design (De Gisi et al., 2016). However, up to now high costs of commercial adsorbents prevent the use of this technique. For this reason, low-cost adsorbents produced from waste materials such as SS are considered as a sustainable solution for waste water treatment (De Gisi et al., 2016). SS is currently mainly landfilled, incinerated or used as agricultural fertilizer and soil improver. However, the deposition of sewage sludge at landfills can give rise to leachates that affect both, soil and groundwater (Bougrier et al., 2006). Given that the amount of SS is steadily increasing new SS valorization technologies need to be developed (Bougrier et al., 2006). Pyrolysis is a potentially suitable option for SS valorization as it produces a solid (char) that can be used as precursor for low-cost adsorbents (Alvarez et al., 2016). The use of such char-based solid adsorbents for ammonia removal from liquid streams may present an economic solution (Sarkhot et al., 2013) as such char could (partially) replace commercial adsorbents and, at the same time, help to minimize the amount of waste produced in the plant. On-site utilization of SS could boost the circular economy in wastewater treatment plants. Ammonium loaded SS char could be used as solid slow-release fertilizer (Spokas et al., 2012) in the case that ammonium desorption is not easily feasible. Otherwise, efficient ammonium desorption could produce an ammonium rich liquid (Sancho et al., 2017).

Numerous previous studies demonstrated the feasibility of using char from lignocellulosic materials for $\mathrm{NH}_{4}^{+}$retention (Tian et al., 2016) with $\mathrm{NH}_{4}^{+}$retention capacities ranging between $1.5 \mathrm{mg} \mathrm{g}^{-1}$ (Hou et al., 2016) to $6 \mathrm{mg} \mathrm{g}^{-1}$ (Zhang et al., 2014). An even larger value of about $40 \mathrm{mg} \mathrm{g}^{-1}$ was observed for poultry litter char (Jassal et al., 2015). The few studies on $\mathrm{NH}_{4}^{+}$adsorption by char from sewage found low capacities between 0.8 (Beckinghausen et al., 2020) and $2 \mathrm{mg} \mathrm{g}^{-1}$ (Zhang and Wang, 2016). An only moderate adsorption capacity is expected given the high ash content and low organic matter fraction in SS char. For that reason, it seems necessary to activate SS char to increase the number of adsorption sites and to improve its adsorptive properties, e.g., through partial oxidation. The feasibility of this idea has been shown in previous studies, mainly focusing on char from lignocellulosic biomass. Partial oxidation can increase the density of oxygenated functional groups on the surface of char (Figueiredo et al., 1999) and improvements in the $\mathrm{NH}_{4}^{+}$adsorption capacity following char oxidation have been reported (Sanford et al., 2019). The increased adsorption capacity has been explained with increased electrostatic interactions between ammonium cations and negatively charged or polarized oxygen-containing acidic functional groups on the char surface (Banik et al., 2018) such as carboxylic acids or carboxylic anhydrides, lactones, lactols, and phenolic hydroxyls (Shafeeyan et al., 2010).

Compared to char from lignocellulosic biomass, the ash content in SS char is particularly high (Fonts et al., 2009). This SS mineral matter is mainly composed of $\mathrm{Al}, \mathrm{Fe}, \mathrm{Si}, \mathrm{Ca}$ and $\mathrm{P}$ (Ruiz-Gómez et al., 2017). Some inorganic compounds, such as pyrite (Wang et al., 2003) and calcium carbonate (Sujant and Zhang, 2000) promote the oxidation process while others such as phosphates inhibit it (Raymond et al., 2016)). The presence of relatively high amounts of $\mathrm{N}$ and $\mathrm{S}$ is also a particularity of SS char. $\mathrm{N}$ and S-containing functional groups can participate in the oxidation process as well (Grzybek and Kreiner, 1997). This unique composition of SS char implies that knowledge obtained from coal or lignocellulosic char oxidation is not directly applicable to SS char. Due to this gap a good understanding on SS char oxidation has yet to emerge. One motivation of the current work is to provide experimental data needed to assess how partial oxidation of SS char affects the char surface composition.

Most of the previous char oxidation studies use oxidant reagents such as nitric and sulfuric acid (Anstey et al., 2016), sodium hypochlorite (Sanford et al., 2019) or hydrogen peroxide (Wang et al., 2016a). The general conclusion of these studies is that $\mathrm{NH}_{4}^{+}$ adsorption can be increased two-to threefold compared to original biochar if the biochar pH was adjusted to 7 (Wang et al., 2016a). An increase in the concentration of acidic functional groups on lignocellulosic biomass char surface through oxidation by molecular oxygen (air) has also been reported (Tangsathitkulchai et al., 2009). Air oxidation is a more economic and easier to implement activation process than oxidation by chemical oxidants. However, the oxidation results should strongly depend on operating parameters such as temperature, oxygen concentration and reaction time. To the best of our knowledge, the activation of SS char with oxygen and the effect of the parameters process on the char oxidation degree have not yet been studied. If feasible, it would be an interesting method to improve its adsorption capacity, because air oxidation could be easily integrated into the char cooling step in wastewater treatment plants with a pyrolysis process coupled to anaerobic digestion treatment (Wang et al., 2016b). SS char activated by oxygen would then be on-site used as low-cost adsorbent to reduce the $\mathrm{NH}_{4}^{+}$concentration in the side stream rejection water to better meet the regulatory discharge limits and simultaneously to minimize the amount of waste generated in a waste water treatment plant.

In this study, the activation of SS char through partial oxidation is evaluated with the goal to establish conditions at which the concentration of $\mathrm{O}$-containing surface functional groups can be increased without burnout of char. Char characterization is carried out to compare non-oxidized and oxidized solids and the mass change, temperature change in the reactor, the oxygen consumption and the formation of oxidation products in the gas and solid phases are examined. Finally, preliminary results for $\mathrm{NH}_{4}^{+}$adsorption on oxidized SS chars will be presented to demonstrate that activation with oxygen enhances the ammonium adsorption capacity of SS char.

\section{Materials and experimental methods}

This section describes the production of un-oxidized char, which is the starting material of this study, the experimental procedures which were followed to activate SS char and the techniques used to characterize both un-oxidized char and the products obtained from the oxidation of char. Finally, the initial $\mathrm{NH}_{4}^{+}$adsorption tests are described.

\subsection{Materials}

Char was produced by pyrolysis of anaerobically digested and thermally dried sewage sludge (SS) supplied by an urban wastewater treatment plant located in Madrid (Spain). Information about SS properties can be found elsewhere (Ruiz-Gómez et al., 2017). The pyrolysis was performed in a fixed-bed reactor of $1 \mathrm{~kg}$ of capacity (Ábrego et al., 2018) in $\mathrm{N}_{2}$ atmosphere $\left(250 \mathrm{~mL}(\mathrm{STP}) \mathrm{min}^{-1}\right.$ ). A heating rate of approximately $5{ }^{\circ} \mathrm{C} \mathrm{min}^{-1}$ was applied to reach the final temperature of $550{ }^{\circ} \mathrm{C}$, which was maintained for $30 \mathrm{~min}$. The char yield obtained was 52 wt \%, expressed as a percentage of weight of the SS fed into the reactor. For usage in the fixed bed reactor, the char was ground and sieved to a uniform particle size between 250 and $500 \mu \mathrm{m}$. Char properties are reported in the Results section in comparison to oxidized char properties. Specifically, elemental analysis, ash content, specific surface area, micropore volume, average pore diameter, FTIR analysis and XPS analysis are reported in section 3.2.3 (see Tables 2 and 4-6). 


\subsection{Experimental setups used for char oxidation}

In this work, two different experimental setups were used to study char oxidation. The thermobalance provides a well-defined and easy to control environment while the conditions in a labscale fixed bed reactor are more realistic in terms of technical applications. Details of both setups are given below.

\subsubsection{Lab-scale fixed bed reactor}

Char oxidation runs were performed in a lab-scale fixed bed reactor (internal diameter $=12 \mathrm{~mm}$ and length $=400 \mathrm{~mm}$ ) using $1.5 \mathrm{~g}$ of char (Fig. 1). Prior to the oxidation step, char was heated in a $\mathrm{N}_{2}$ stream of $50 \mathrm{~mL}(\mathrm{STP}) \mathrm{min}^{-1}$ to the desired oxidation temperature $\left(200,275\right.$ or $\left.350^{\circ} \mathrm{C}\right)$. The temperature was measured with the thermocouple of the temperature controller, which was placed in the centre of the char bed. Once the oxidation temperature was reached, a mixture of air and $\mathrm{N}_{2}$ with a total flowrate of $50 \mathrm{~mL}$ (STP) $\mathrm{min}^{-1}$ and an oxygen concentration between 5 and $21 \mathrm{vol} \%$ was fed into the reactor. The selected oxidation condition was maintained throughout the duration of the experiment (30-120 min). The outlet gases passed through a condenser prior to being analyzed online by gas chromatography. Except for a few colorless presumably water droplets no liquid was retained in the vapor condensation system. The amount of the droplets was too small in comparison to the weight of the condensation system to allow a quantitative analysis by mass difference. The composition of the non-condensable gases evolving from the fixed-bed reactor was continuously analyzed by a micro gas chromatograph (micro GC). The identified and quantified gases were $\mathrm{N}_{2}, \mathrm{O}_{2}, \mathrm{CO}_{2}$ and $\mathrm{CO}$, using $\mathrm{N}_{2}$ as internal standard. Once the oxidation process had finished, the solid sample was cooled down to ambient temperature under $\mathrm{N}_{2}$ flow. The mass yield of the oxidized char was calculated as the ratio between the mass of the oxidized char and the mass of nonoxidized char introduced into the reactor.

The experiments were planned according to a $2^{3}$ full factorial experimental design using oxidation temperature, oxygen concentration and oxidation duration as independent variables. The oxidation temperatures used were $200{ }^{\circ} \mathrm{C}$ and $350{ }^{\circ} \mathrm{C}$, oxygen concentrations were 5 and $21 \mathrm{vol} \%$ and the reaction times tested were 30 and $120 \mathrm{~min}$. These parameter ranges are broad enough to compare mild and severe process conditions and to disclose their effects on partial oxidative char activation. Additional experiments were performed at the centre point condition $\left(275{ }^{\circ} \mathrm{C}, 13 \mathrm{vol} \%\right.$, $75 \mathrm{~min})$ to investigate if linear trends exist. The experimental variability was evaluated through three replicates performed at the centre point conditions. The results were statistically analyzed by means of analysis of variance (ANOVA) at $90 \%$ confidence level. The runs are referred to as a combination of letters (T: temperature, $\mathrm{O}$ : oxygen concentration, $\mathrm{t}$ : time) followed by numbers indicating the parameters values. For example, T275_013_t75 indicates the centre point condition.

\subsubsection{Thermogravimetric analysis}

Thermogravimetric analyses (TGA) were performed with a Netzsch STA 449 Jupiter ${ }^{\circledR}$ thermobalance prior to the fixed-bed experiments. The oxidation conditions were similar to those used in the fixed bed experiments with the exception of the centre point that was not tested in the thermobalance system. SS was ground and sieved to a particle size below $50 \mu \mathrm{m}$. The operating conditions used for the pyrolysis step prior to oxidation were the same for all the runs: $75 \mathrm{mg}$ of SS was heated up to $550{ }^{\circ} \mathrm{C}$ at a heating rate of $10{ }^{\circ} \mathrm{C} \mathrm{min}^{-1}$ in $\mathrm{N}_{2}$ atmosphere (flow rate of $100 \mathrm{~mL}(\mathrm{STP}) \mathrm{min}^{-1}$ ) and maintained at $550{ }^{\circ} \mathrm{C}$ for $30 \mathrm{~min}$. Afterwards, the sample was cooled down to the oxidation temperature. Once the desired oxidation temperature was reached the appropriate air and $\mathrm{N}_{2}$ mixture was introduced with a constant total flowrate of $100 \mathrm{~mL}$ (STP) $\min ^{-1}$. The sample was kept in the oxidative atmosphere for the selected oxidation time. After the oxidation process had finished, the solid sample was cooled down to ambient temperature in a $\mathrm{N}_{2}$ flow.

\subsection{Characterization of products}

The un-oxidized and oxidized chars were characterized by ash content, elemental analysis, textural properties, and Fourier Transform Infrared and X-ray Photoelectron spectroscopy. The composition of the gaseous product from char oxidation was also determined.

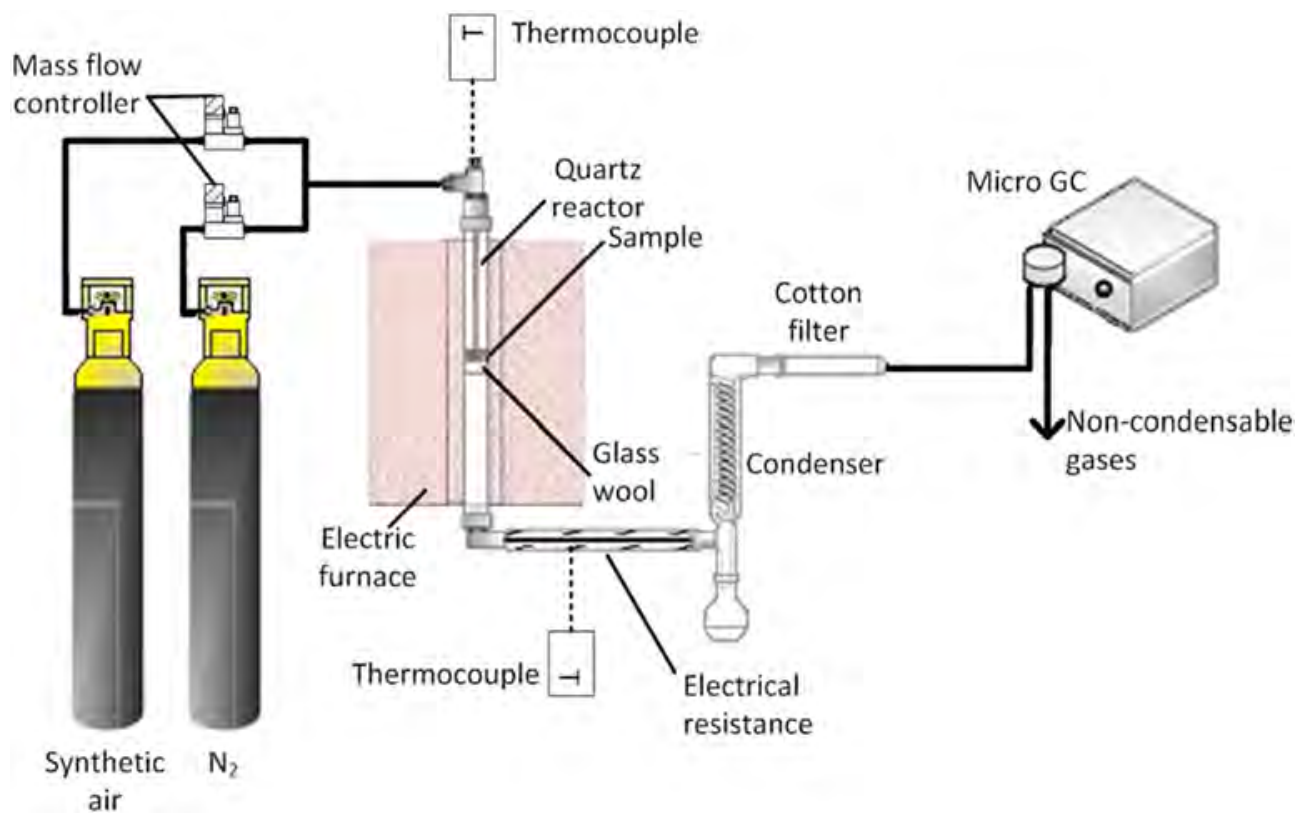

Fig. 1. Schematic diagram of the lab-scale experimental setup. 


\subsubsection{Char characterization}

Both the non-oxidized and oxidized char samples were characterized using several analytical techniques.

The ISO-18122-2015 standard was applied to determine the ash content of the samples. Elemental analysis was performed using a Truspec-CHN® (LECO) elemental analyzer and the oxygen content was determined by difference taking into account the ash content. These data were used to calculate the $\mathrm{H} / \mathrm{C}$ and $\mathrm{O} / \mathrm{C}$ ratios.

The specific surface area and pore structure of the samples were determined by $\mathrm{CO}_{2}$ adsorption isotherms at $273 \mathrm{~K}$ on a Quantachrome Autosorb ${ }^{\circledR} 6$ Surface Area and Pore Size Analyzer. The samples were degassed at $523 \mathrm{~K}$ for $8 \mathrm{~h}$ prior to each analysis. Specific surface area and micropore volume were calculated using the Dubinin-Radushkevich (DR) equation.

Char samples were also characterized by Attenuated Total Reflection-Fourier Transform Infrared (ATR-FTIR) spectroscopy using an Agilent Cary 600 FTIR spectrometer, with a resolution of $4 \mathrm{~cm}^{-1}$ in the wavelength range of $4000-400 \mathrm{~cm}^{-1}$ (medium IR region). The chemical bonds at the external surface layer of the samples were characterized by X-ray Photoelectron Spectroscopy (XPS) using a Kratos AXIS Supra XPS spectrometer with a monochromatic Al K $\alpha$ X-ray source (photon energy: $1486.6 \mathrm{eV}$ ). Curve fitting of $\mathrm{C} 1 \mathrm{~s}$ and $\mathrm{O}$ 1s data was performed with version 2.3 .15 of CasaXPS software. The binding energy scale was set to a value of $284.9 \mathrm{eV}$ for the graphitic carbon $\mathrm{C}$ 1s peak. The main elements present in the char surface (C, O, N, S, Fe, Ca, P, Si and P) were analyzed and their relative atomic fractions were calculated. XPS analysis was performed by Institute of Nanoscience of Aragon.

\subsubsection{Gas characterization}

The amounts of $\mathrm{O}_{2}$ consumed and $\mathrm{CO}_{2}$ and $\mathrm{CO}$ generated in the char oxidation runs performed in the lab-scale fixed-bed reactor were calculated from the micro GC analyses. The ratio between the stoichiometric amount of $\mathrm{O}_{2}$ required to generate the $\mathrm{CO}_{2}$ and $\mathrm{CO}$ produced $\left(\mathrm{O}_{2}\right.$ Carbonlost $)$ and the total $\mathrm{O}_{2}$ consumed during the oxidation process $\left(\mathrm{O}_{2}\right.$ consumed $)$ was also calculated.

\subsection{Ammonium adsorption testing}

Preliminary $\mathrm{NH}_{4}^{+}$adsorption tests were conducted in $50 \mathrm{~mL}$ conical flasks at ambient temperature. $0.4 \mathrm{~g}$ of char was added to $10 \mathrm{~mL}$ of $\mathrm{NH}_{4} \mathrm{Cl}$ solution ( $1000 \mathrm{mg} \mathrm{L}^{-1}$ of $\mathrm{N}$ ). The conical flasks were shaken with an orbital agitator for $24 \mathrm{~h}$. Next, the suspension was decanted and filtered through a $45 \mu \mathrm{m}$ Millipore ${ }^{\circledR}$ polytetrafluoroethylene membrane filter. The $\mathrm{NH}_{4}^{+}$concentration in the initial $\mathrm{NH}_{4} \mathrm{Cl}$ solution and the filtrate was measured using an Ion Chromatograph (Metrohm, 930 Compact IC Flex). The $\mathrm{NH}_{4}^{+}$ adsorption capacity was calculated by mass balance.

\section{Results and discussion}

In the following section the experimental results obtained for char oxidation and for the preliminary $\mathrm{NH}_{4}^{+}$adsorption tests are presented and arguments will be given that partial oxidation of SS char with oxygen leads at suitable conditions to surface changes of the char that improve its capability to adsorb $\mathrm{NH}_{4}^{+}$.

\subsection{Thermogravimetric analysis}

In the TGA experiments SS samples were first pyrolyzed to char, which was subsequently oxidized to activated char. The mass loss profiles during the pyrolysis step were very similar proving high reproducibility of this step (see Figure $\mathrm{S} 1$ ). The subsequent oxidation step showed marked differences mainly depending on the oxidation temperature: a slight increase in the mass of solid was
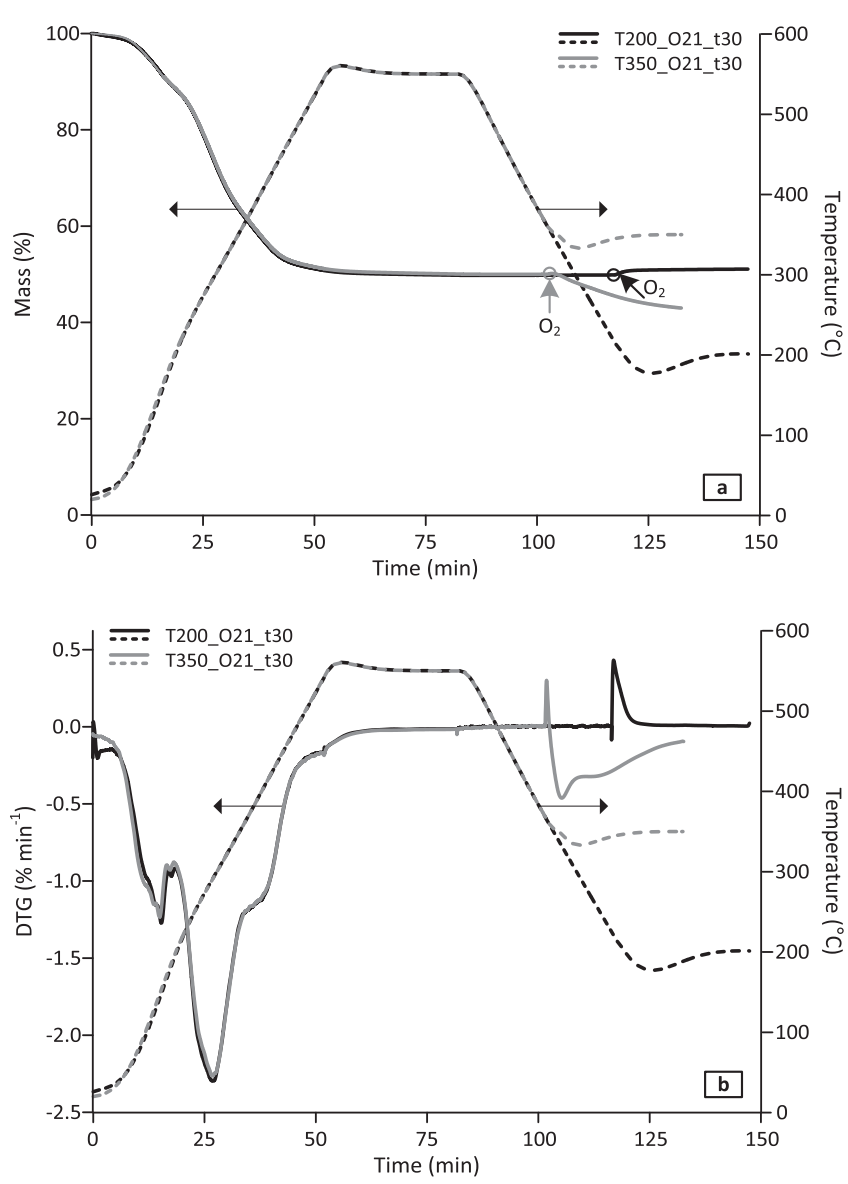

Fig. 2. a) TG and b) DTG curves for oxidation experiments T200_021_t30 and T350_021_t30 performed in the thermobalance. Circles indicate the time at which $\mathrm{N}_{2}$ was replaced by the $\mathrm{N}_{2} / \mathrm{O}_{2}$ mixture.

always observed at the beginning, which in the case of the experiments performed at $350^{\circ} \mathrm{C}$ was followed by a significant mass loss. For the sake of simplicity, only two representative TG/DTG profiles are presented in Fig. 2 (T200_O21_t30 and T350_O21_t30) to illustrate this behaviour. All the TG/DTG profiles are available in the Supplementary Information (Figure S1).

Zhan et al. (2014) reported TG results for coal oxidation in dynamic runs up to $400{ }^{\circ} \mathrm{C}$ and a similar trend for the mass change was observed. In that study, the sample mass under oxidation conditions increased up to $275^{\circ} \mathrm{C}$ and then decreased by increasing temperature. The oxidation mechanism might be described as two parallel steps (Su et al., 2017): (1) char is directly oxidized to volatile products $\left(\mathrm{CO}_{2}, \mathrm{CO}\right.$ and $\left.\mathrm{H}_{2} \mathrm{O}\right)$ or (2) it initially reacts to form intermediate surface species, which subsequently either continue to react to gases or alternatively are stabilized as functionalized groups (hydroxyl and phenolic $(-\mathrm{OH})$, carbonyl $(-\mathrm{CO})$, carboxyl $(-\mathrm{COOH})$ and ether (C-O-C) linkages (Zhan et al., 2014)). The mass gain during oxidation is attributed to oxygen uptake and the formation of solid oxygenated complexes (Zhan et al., 2014).

Table 1 presents the mass yields of the oxidized chars obtained from TG. These yields were calculated as the ratio between the mass at the end and at the beginning of the oxidation step. Char yields higher than $100 \mathrm{wt} \%$ indicate a mass gain due to oxidation. This mass gain at mild oxidation conditions $\left(200^{\circ} \mathrm{C}\right)$ implies that oxygen was incorporated into the sample, part of it possibly in form of the desired oxygenated functional groups. However, taking into account the unique composition of SS char, the oxidation of other 
Table 1

Oxidized char yield in TGA and fixed-bed reactor system.

\begin{tabular}{lll}
\hline Run ID & \multicolumn{2}{l}{ Oxidized char yield (wt. \%) } \\
\cline { 2 - 3 } & TGA & Fixed-bed reactor \\
\hline T200_05_t30 & 101.9 & 101 \\
T200_O5_t120 & 102.6 & 99 \\
T200_O21_t30 & 102.4 & 98 \\
T200_O21_t120 & 102.7 & 97 \\
T350_05_t30 & 91.2 & 97 \\
T350_05_t120 & 83.5 & 89 \\
T350_O21_t30 & 85.9 & 92 \\
T350_O21_t120 & 81.6 & 75 \\
T275_013_t75 & n. a. & $94 \pm 1$ \\
\hline
\end{tabular}

a Average value \pm standard deviation (3 replicates). ${ }^{\mathrm{b}}$ Not available.

elements such as $\mathrm{N}$ and $\mathrm{S}$, and some mineral elements present in the non-oxidized char may also contribute to the mass gain observed (Bardestani and Kaliaguine, 2018). To address this possibility an in-depth char characterization was performed in this work, which will be discussed later. The mass loss during char oxidation at $350{ }^{\circ} \mathrm{C}$ is caused by removal of organic matter in the form of volatile species, mainly $\mathrm{CO}, \mathrm{CO}_{2}$ and $\mathrm{H}_{2} \mathrm{O}$.

At $200{ }^{\circ} \mathrm{C}$ neither the oxidation time nor the oxygen concentration had a significant effect on the observed mass gain, while at the highest temperature $\left(350{ }^{\circ} \mathrm{C}\right)$ an increase of either parameter value favored the mass loss.

\subsection{Fixed-bed reactor oxidation}

The results obtained from char oxidation in the fixed bed reactor include temperature evolution inside the reactor, char yield and characterization, and gaseous product composition.

\subsubsection{Temperature evolution in the fixed-bed reactor}

The temperature in the char bed during the oxidation step using the fixed-bed reactor system was continuously recorded in all runs performed. For the sake of simplicity and in order to show the general behaviour of the oxidation process, Fig. 3 only displays data obtained for the experiments with an oxidation step of $30 \mathrm{~min}$, and also for the centre point conditions (averaged profile of the replicates). For all conditions tested except for the runs performed at $200{ }^{\circ} \mathrm{C}$, a temperature increase was observed after introduction of

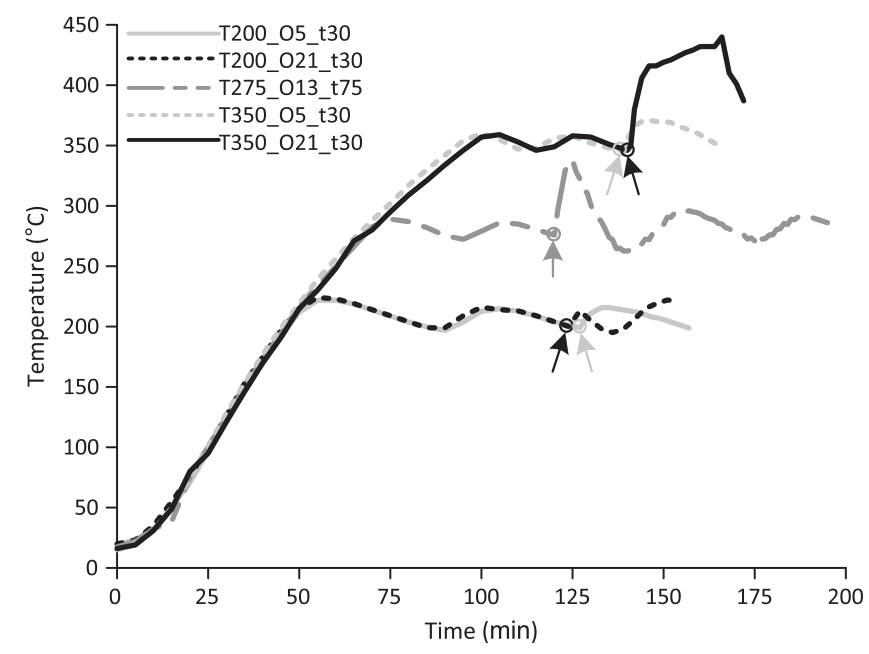

Fig. 3. Temperature-time profiles during the oxidation step. Arrows indicate the time at which $\mathrm{N}_{2}$ was replaced by the $\mathrm{N}_{2} / \mathrm{O}_{2}$ mixture. oxygen. This increase is caused by exothermic oxidation reactions. As other authors pointed out, the temperature increase observed is due to the heat released by the exothermic reactions during the oxidation process being larger than that consumed by the endothermic reactions (Wang et al., 2003). A higher oxygen concentration resulted in a more pronounced temperature increase (Fig. 3) as other authors have also observed (Zhan et al., 2014). The strong temperature increase under the most severe conditions is probably due to burn-off reactions (Zhan et al., 2014). The oxidation process releases energy that locally increases the bed temperature and accelerates the combustion reactions and the extent of burn-off. If heat removal is not efficient enough, thermal runaway may occur. Since inefficient heat removal may cause thermal runaway, the oxidation temperature must be carefully controlled to avoid complete oxidation of char. The reactor for the process should be designed with efficient heat management in mind to ensure that the rate of heat generation due to the oxidation reactions does not exceed the heat removal rate by the cooling system.

\subsubsection{Oxidized char yields}

The char yields obtained after the oxidation step in the fixedbed reactor system are shown in Table 1.

Oxidation temperature was the most influential factor and it negatively affected the oxidized char yields. Char yields ranged from $89 \mathrm{wt} \%$ to $101 \mathrm{wt} \%$, except for the run performed at the most severe conditions ( $350{ }^{\circ} \mathrm{C}$ with $21 \mathrm{vol} \% \mathrm{O}_{2}$ for $120 \mathrm{~min}$ ), which presented the lowest yield ( $75 \mathrm{wt} \%$ ). At latter conditions, the mass loss during the oxidation step was even more pronounced, indicating that burn-off reactions of the carbonaceous matter of the char dominated. The yields obtained in the TGA experiments differ from those obtained in the fixed bed reactor experiments, but the observed trends were similar. Several factors could explain the differences observed between both experimental systems: (i) the higher oxygen flowrate relative to the char amount in the TGA runs, (ii) the higher instability of set point temperatures and the bigger particle size in the fixed bed reactor, and (iii) the higher resistances to mass and heat transfer in the fixed-bed reactor.

\subsubsection{Char characterization}

Oxidized chars have been characterized by elemental analysis, CO2 physisorption, FTIR and XPS. The results are presented in the following paragraphs and comparisons with those for un-oxidized char are made.

3.2.3.1. Elemental composition and ash content. The elemental analyses and the ash contents of both non-oxidized chars and char samples oxidized in the fixed-bed reactor are listed in Table 2. The oxygen contents of all oxidized chars are higher than that of the non-oxidized reference sample. Oxidation temperature, oxygen concentration and oxidation time promoted the increase in the oxygen content. The ANOVA analysis of the data showed significant curvatures meaning that the degree of surface oxidation did not vary linearly with any of the oxidation parameters ( $p_{\text {value }}<0.1$ in the ANOVA analysis). The $\mathrm{C}$ and $\mathrm{H}$ contents decreased significantly at oxidation temperatures higher than $200{ }^{\circ} \mathrm{C}$ compared to those of non-oxidized char, reaching the lowest values after the most severe oxidation treatment. This points to burning-off reactions that took place to a larger extent under those conditions. The clear increase in the ash content of the oxidized char obtained at the most severe conditions also supported that fact. However, the $\mathrm{N}$ and $\mathrm{S}$ contents were less variable with the oxidation treatment. The mass balance for $\mathrm{N}$ and $\mathrm{S}$ (Table 3 ) revealed that only small quantities of $\mathrm{N}$ and $\mathrm{S}$ were lost during the oxidation, with the exception of the runs performed at $350{ }^{\circ} \mathrm{C}$. However, $\mathrm{H}$ was lost even at the mildest oxidation conditions (Table 3 ), probably due to water formation 
Table 2

Elemental composition, ash content (wt. \%) and atomic ratios (ash free basis) of the chars.

\begin{tabular}{|c|c|c|c|c|c|c|c|c|}
\hline Sample ID & C (wt. \%) & H (wt. \%) & N (wt. \%) & S (wt. \%) & $\mathrm{O}^{\mathrm{a}}$ (wt. \%) & Ash (wt. \%) & $\mathrm{O} / \mathrm{C}$ & $\mathrm{H} / \mathrm{C}$ \\
\hline Non-oxidized & 22.1 & 1.01 & 2.7 & 1.6 & 1.8 & 70.8 & 0.06 & 0.55 \\
\hline T200_05_t30 & 22.1 & 0.77 & 2.7 & 1.7 & 2.3 & 70.4 & 0.08 & 0.42 \\
\hline T200_05_t120 & 22.2 & 0.76 & 2.8 & 1.6 & 2.3 & 70.3 & 0.08 & 0.41 \\
\hline T200_021_t30 & 21.9 & 0.94 & 2.7 & 1.7 & 3.2 & 69.6 & 0.11 & 0.52 \\
\hline T200_O21_t120 & 21.5 & 0.86 & 2.7 & 1.6 & 4.6 & 68.7 & 0.16 & 0.48 \\
\hline T350_05_t30 & 21.0 & 0.83 & 2.7 & 1.4 & 3.9 & 70.2 & 0.14 & 0.47 \\
\hline T350_05_t120 & 16.6 & 0.75 & 2.8 & 1.3 & 6.3 & 72.2 & 0.28 & 0.54 \\
\hline T350_021_t30 & 14.5 & 0.71 & 2.2 & 1.4 & 5.9 & 75.3 & 0.31 & 0.59 \\
\hline T350_O21_t120 & 4.0 & 0.35 & 1.1 & 1.5 & 6.2 & 86.8 & 1.16 & 1.05 \\
\hline T275_013_t75 & $19.7 \pm 0.3$ & $0.66 \pm 0.04$ & $2.7 \pm 0.1$ & $1.5 \pm 0.1$ & $6.4 \pm 0.8$ & $69.1 \pm 0.8$ & $0.24 \pm 0.01$ & $0.40 \pm 0.02$ \\
\hline
\end{tabular}

${ }^{a}$ Oxygen (\%) = 100 - carbon (\%) - hydrogen (\%) - nitrogen (\%) - sulfur (\%) - ash (\%).

b Average value \pm standard deviation (3 replicates).

Table 3

Ratio, expressed in percentage, between the mass of $\mathrm{N}, \mathrm{S}, \mathrm{H}$ and $\mathrm{C}$ contained in the oxidized char ( $\mathrm{N}_{\text {out }}, \mathrm{S}_{\text {out }}, \mathrm{H}_{\text {out }}$ and $\left.\mathrm{C}_{\text {out }}\right)$ and the non-oxidized char $\left(\mathrm{N}_{\mathrm{in}}, \mathrm{S}_{\mathrm{in}}, \mathrm{H}_{\text {in }}\right.$ and Cin).

\begin{tabular}{lllll}
\hline Sample ID & $\mathrm{N}_{\text {out }} / \mathrm{N}_{\text {in }}(\%)$ & $\mathrm{S}_{\text {out }} / \mathrm{S}_{\text {in }}(\%)$ & $\mathrm{H}_{\text {out }} / \mathrm{H}_{\text {in }}(\%)$ & $\mathrm{C}_{\text {out }} / \mathrm{C}_{\text {in }}(\%)$ \\
\hline T200_05_t30 & 100 & 100 & 81 & 100 \\
T200_05_t120 & 100 & 99 & 79 & 99 \\
T200_O21_t30 & 98 & 100 & 88 & 97 \\
T200_O21_t120 & 97 & 97 & 87 & 94 \\
T350_05_t30 & 97 & 85 & 78 & 92 \\
T350_05_t120 & 92 & 72 & 71 & 67 \\
T350_O21_t30 & 75 & 81 & 64 & 60 \\
T350_021_t120 & 31 & 70 & 30 & 14 \\
T275_013_t75 & $98 \pm 1$ & $92 \pm 3$ & $66 \pm 3$ & $88 \pm 2$ \\
\hline
\end{tabular}

a Average value \pm standard deviation (3 replicates).

during the oxidation process, since it is one of the most important gaseous products that arise from oxidation (Wang et al., 2003).

The $\mathrm{O} / \mathrm{C}$ and $\mathrm{H} / \mathrm{C}$ ratios shown in Table 2 indicate how the operating conditions affected the oxygen content in char. The $\mathrm{O} / \mathrm{C}$ ratio increased in all experiments with the highest value observed at the most severe oxidation condition $\left(350{ }^{\circ} \mathrm{C}, 21\right.$ vol $\% \mathrm{O}_{2}$, $120 \mathrm{~min})$. However, at these oxidation conditions the organic matter content of the char was very low as the high ash content of $86.8 \mathrm{wt} \%$ shows. In contrast, the ash contents of the chars oxidized at $200-275{ }^{\circ} \mathrm{C}$ were similar to that of the non-oxidized reference sample. This suggests that the mass gain observed in the TGA analyses for the chars obtained under mild oxidation conditions can indeed be ascribed to oxygen incorporation into the organic char fraction, that is an increase in the amount of oxygenated functional groups, and not to the oxidation of the mineral matter. Since oxygen was calculated by difference, the $\mathrm{O} / \mathrm{C}$ values have relatively high uncertainties and additional analyses are required to corroborate the partial oxidation of char. Regarding the $\mathrm{H} / \mathrm{C}$ ratio, it decreased after oxidation under mild conditions compared to nonoxidized char, and increased after oxidation at $350{ }^{\circ} \mathrm{C}$ and $21 \mathrm{vol} \%$ $\mathrm{O}_{2}$. The increase at $350{ }^{\circ} \mathrm{C}$ can be explained with $\mathrm{C}$ loss due to full oxidation to $\mathrm{CO}_{2}$.

3.2.3.2. $\mathrm{CO}_{2}$ physisorption analysis. Non-oxidized chars and oxidized char samples produced in the fixed-bed reactor were analyzed by $\mathrm{CO}_{2}$ adsorption (applying the Dubinin-Radushkevich equation) to evaluate the effect of the operating conditions on their textural characteristics, including specific surface area, micropore volume and average pore diameter. The results are summarized in Table 4. According to the first column in Table 4, the oxidation of SS char hardly affects its textural properties with the exception of chars oxidized under the most severe conditions, which showed the lowest specific surface area and micropore volume. This trend is apparently contrary to those found in the literature: surface area of chars tends to increase with an increase in the treatment severity (Bardestani and Kaliaguine, 2018; Suliman et al., 2016; Xiao et al., 2018). The reason for this different behavior can be attributed to the high ash content of SS chars. The inorganic content of chars can be assumed to contribute negligibly to surface area (Monsalvo et al., 2011). If surface area is calculated on an ash-free basis (column 2 of Table 4), a clear increasing trend of surface area with oxidation temperature can be observed.

3.2.3.3. FTIR analysis. The presence of oxygenated functional groups on the surface of char plays an important role in its use as adsorbent material as for example for $\mathrm{NH}_{4}^{+}$retention (Wang et al., 2015). FTIR spectroscopy has been used to get information about the chemical structure of carbonaceous materials (Shafeeyan et al., 2010). When applied to ash-rich materials such as SS char the interpretation of FTIR spectra becomes complicated because the ash creates many additional bands, which obscure some contributions from oxygenated functional groups (Saha and Kienbaum, 2019). Fig. 4 shows the spectra of non-oxidized and oxidized char samples. The region between $2200-1980 \mathrm{~cm}^{-1}$ has been ignored since it corresponds to the absorption band for the diamond crystal of the FTIR spectroscopy accessory. The band between 1700 and $1250 \mathrm{~cm}^{-1}$ could result from $\mathrm{C}=\mathrm{O}$ stretching modes of ketones, aldehydes, lactones, quinones or carboxyl groups and $\mathrm{OH}$ deformation of carboxylic acids (Shafeeyan et al., 2010). The presence of peaks in this absorption band compared to only a small bump in non-oxidized char supports the interpretation that oxidative activation of char enhances the concentration of oxygen-containing functional groups. The broad band observed between 1250 and $810 \mathrm{~cm}^{-1}$ may include contributions from alcohols and phenolic groups (O-H, C-OH; 1200-1000 $\mathrm{cm}^{-1}$ ) (Ozdemir et al., 2011), ethers (C-O stretching; $1250-1000 \mathrm{~cm}^{-1}$ ) (Shafeeyan et al., 2010), and also phosphates (Youness et al., 2018) and silica (Mosallanejad et al., 2017). Phosphates and silica are indeed part of SS ash. The increase in the intensity of this absorption band could be directly related due to the ash enrichment during the oxidation process.

3.2.3.4. X-ray photoelectron spectroscopy (XPS) analysis. XPS is a surface analysis technique that has been used to investigate the chemical composition at the surface of carbonaceous materials (Shafeeyan et al., 2010). Table 5 shows the atomic ratio between superficial oxygen $\left(\mathrm{O}_{\mathrm{s}}\right)$ and the superficial carbon $\left(\mathrm{C}_{\mathrm{s}}\right)$. The results show an increase of the $\mathrm{O}_{s} / \mathrm{C}_{\mathrm{s}}$ ratio after oxidation, especially for the char oxidized under severe conditions $\left(350{ }^{\circ} \mathrm{C}\right.$ and $\left.21 \% \mathrm{O}_{2}\right)$. An $\mathrm{O}_{\mathrm{s}} / \mathrm{C}_{\mathrm{s}}$ ratio higher than the $\mathrm{O} / \mathrm{C}$ measured by elemental analysis (see Table 2) may be explained by two factors: (1) additional oxygen is bound to the mineral matter on the char surface, and (2) a nonuniform distribution of oxygen atoms due to a higher degree of 
Table 4

Specific surface area, micropore volume and average pore diameter of non-oxidized and oxidized chars.

\begin{tabular}{|c|c|c|c|c|}
\hline Sample ID & Surface area $\left(\mathrm{m}^{2} \mathrm{~g}^{-1}\right)$ & Surface area, ash-free basis $\left(\mathrm{m}^{2} \mathrm{~g}^{-1}\right)$ & Micropore volume $\left(\mathrm{cm}^{3} \mathrm{~g}^{-1}\right)$ & Average pore diameter $(\mathrm{nm})$ \\
\hline Non-oxidized & 112.6 & 385.6 & 0.038 & 0.715 \\
\hline T200_05_t30 & 113.7 & 384.1 & 0.039 & 0.726 \\
\hline T200_05_t120 & 108.4 & 365.0 & 0.037 & 0.714 \\
\hline T200_021_t30 & 105.7 & 347.7 & 0.036 & 0.722 \\
\hline T200_O21_t120 & 106.9 & 341.5 & 0.036 & 0.722 \\
\hline T350_05_t30 & 118.2 & 396.6 & 0.040 & 0.717 \\
\hline T350_05_t120 & 124.6 & 448.2 & 0.042 & 0.733 \\
\hline T350_021_t30 & 95.6 & 387.0 & 0.033 & 0.718 \\
\hline T350_021_t120 & 61.8 & 468.2 & 0.021 & 0.767 \\
\hline T275_013_t75 ${ }^{\mathrm{a}}$ & $117.9 \pm 0.9$ & $381.6 \pm 7.5$ & 0.040 & $0.715 \pm 0.006$ \\
\hline
\end{tabular}

a Average value \pm standard deviation (3 replicates).

oxidation on the surface than in the bulk char. The $\mathrm{O}_{s} / \mathrm{C}_{\mathrm{s}}$ ratio in this study differs from those reported for other types of biomass like lignocellulosic materials, which show similar results for both $\mathrm{O} / \mathrm{C}$ measured by elemental analysis and $\mathrm{O}_{s} / \mathrm{C}_{\mathrm{s}}$ (Suliman et al., 2016). As discussed before, this difference might be attributed to the high ash content of SS chars.

The deconvolution of XPS spectra was performed with the Gaussian-Lorentzian line shape (GLx30\%) and a full width half maximum (FWHM $2 \mathrm{eV}$ ). The $\mathrm{C} 1 \mathrm{~s}$ spectra were deconvoluted into five components, namely the following: graphitic (peak 1, $\mathrm{BE}=284.7 \pm 0.1 \mathrm{eV}$ ), aromatic or aliphatic carbon (peak 2, $\mathrm{BE}=285.3 \pm 0.1 \mathrm{eV}$ ), hydroxyl/phenol/ether carbon (peak 3; $\mathrm{BE}=285.9 \pm 0.1 \mathrm{eV}$ ), carbonyl and carboxyl/ester carbon (peak 4; $\mathrm{BE}=285.9 \pm 0.2 \mathrm{eV}$ ) (Chang et al., 2019), shake-up peaks due to $\pi$ $\pi^{*}$ transition in aromatic rings (peak $5 ; \mathrm{BE}=291.3 \pm 0.2 \mathrm{eV}$ ) (Bardestani and Kaliaguine, 2018). Table 6 shows the changes in the $\mathrm{C}$ bonding states on char surface before and after oxidation. From these data, it can be concluded that the oxidation process led to an increase in the percentage of the total Oxygen Functional Groups (OFGs: sum of all oxygen-containing functional groups $(\mathrm{C}-\mathrm{O} ; \mathrm{C}=\mathrm{O}$; $\mathrm{O}=\mathrm{C}-\mathrm{O})$ ), which implies an increase of oxidized carbon on char surface. If these oxygenated functional groups are of acidic nature this should lead to an improved $\mathrm{NH}_{4}^{+}$adsorption capacity. The oxidized char with the highest percentage of total OFGs (53.20\%) was produced at the most severe oxidation conditions $\left(350{ }^{\circ} \mathrm{C}\right.$, $21 \mathrm{vol} \% \mathrm{O}_{2}, 120 \mathrm{~min}$ ), but this char contained the lowest relative atomic carbon percentage on the surface (26.86\%). Partial oxidation increases the percentage of $\mathrm{C}$ bonded to $\mathrm{O}$-containing groups but if the operational conditions are severe, the oxidation process will also provoke high $\mathrm{C}$ lost and ash enrichment.

Apart from $\mathrm{C} 1 \mathrm{~s}$ and $\mathrm{O} 1 \mathrm{~s}$, the surface concentrations and oxidation states of several other elements ( $\mathrm{N}, \mathrm{Fe}, \mathrm{Si}, \mathrm{Al}, \mathrm{P}, \mathrm{S}$ and $\mathrm{Ca}$ ) were also measured and the results are reported in Supplementary Information (see Table S1a for the relative atomic percentages and Table S1b for relative band intensities). Partial oxidation hardly changes the oxidation states of $\mathrm{Si}, \mathrm{Al}$ and $\mathrm{P}$ and the observed band positions are consistent with the presence of aluminosilicates $(\mathrm{BE}=102.7 \pm 0.1 \mathrm{eV})$ and silica $(\mathrm{BE}=103.6 \pm 0.1 \mathrm{eV})$, alumina $(\mathrm{BE}=74.7 \pm 0.1 \mathrm{eV})$, and phosphate $(\mathrm{BE}=133.4 \pm 0.1 \mathrm{eV}$ and $\mathrm{BE}=134.3 \pm 0.1 \mathrm{eV}$ ) (Jović et al., 2014). For $\mathrm{Ca}^{2+}$ ions, which obviously cannot be further oxidized, interesting results were obtained. First, the surface concentration of $\mathrm{Ca}^{2+}$ increased in the $350{ }^{\circ} \mathrm{C}$ oxidation experiments relative to those at $200{ }^{\circ} \mathrm{C}$, and second, the relative intensities of the two $2 \mathrm{p}$ bands varied in the experiments. These facts suggest that $\mathrm{Ca}^{2+}$ ions experience significant changes in their chemical environment during partial oxidation. The oxidation state of $\mathrm{S}$ (thiols at $\mathrm{BE}=164.4 \pm 0.4 \mathrm{eV}$ and sulfites at $\mathrm{BE}=167.5 \pm 0.4 \mathrm{eV}$ to sulfates at $\mathrm{BE}=169.1 \pm 0.3 \mathrm{eV}$ and $170.2 \pm 0.3 \mathrm{eV}$ (Thermo Scientific, 2013), and $\mathrm{N}$ (pyridinic-N at $\mathrm{BE}=398.7 \pm 0.1 \mathrm{eV}$ to pyridonic- $\mathrm{N}$ at $\mathrm{BE}=400.5 \pm 0.2 \mathrm{eV}$ )
(Wójtowicz et al., 1995) increased by the oxidation process, especially at $350{ }^{\circ} \mathrm{C}$ (see Supplementary Information, Table S1b). Considering these changes, one possible explanation for the $\mathrm{Ca}$ results could be that calcium carbonate, sulfate and nitrate are produced. The $2 \mathrm{p}$ band positions and intensities of many calcium minerals are rather similar (Demri and Muster, 1995) and the current XPS data do not allow the determination of which calcium compounds are present and in which amount.

\subsubsection{Gas characterization}

The yield of each gas obtained in the oxidation process in the fixed-bed reactor system was calculated as the ratio in percentage between the mass of gaseous product, calculated from the micro GC data, and the mass of non-oxidized char introduced in the reactor. The main gas produced during the oxidation process was $\mathrm{CO}_{2}$, as can be seen in Table 7. Very small amounts of $\mathrm{CO}_{2}$ were produced during the oxidation process at $200{ }^{\circ} \mathrm{C}$, but the $\mathrm{CO}_{2}$ yield increased significantly when char was oxidized at $350{ }^{\circ} \mathrm{C}$. This is explained with complete oxidation that took place to a notable extent under those severe conditions. Increased oxidation times and the oxygen concentrations also favored the $\mathrm{CO}_{2}$ production, but both operational parameters affected the yield of $\mathrm{CO}_{2}$ to a lesser extent than the oxidation temperature. $\mathrm{CO}$ was only detected in the experiments performed at temperatures equal to or higher than $275^{\circ} \mathrm{C}$, and its yield was always much lower than that of $\mathrm{CO}_{2}$. The presence of $\mathrm{CO}$ could indicate that partial oxidation reactions gained importance. Similar to $\mathrm{CO}_{2}$, longer oxidation times and higher oxygen concentrations led to higher $\mathrm{CO}$ production. The results obtained for the gas yield are consistent with the oxidized char yield data.

The total yield of gas was calculated as the sum of the yield of $\mathrm{CO}_{2}$ and $\mathrm{CO}$. The results are shown in Fig. 5. Since $\mathrm{CO}_{2}$ is the major gas component produced, the total gas yield shows the same trends than seen for $\mathrm{CO}_{2}$.

Fig. 6a-c displays the temporal evolution of $\mathrm{CO}_{2}, \mathrm{CO}$ and $\mathrm{O}_{2}$ concentration (vol. \%) during the oxidation process at different temperatures and oxygen concentrations. Only oxidation data obtained in the $120 \mathrm{~min}$ experiments are displayed, since the gas evolution for $30 \mathrm{~min}$ coincides for both oxidation times. For oxidation at $200{ }^{\circ} \mathrm{C}$ (Fig. 6a), the oxidation time is less important than at $350^{\circ} \mathrm{C}$. Oxidation times shorter than 30 min seem sufficient to achieve complete oxidation at $200{ }^{\circ} \mathrm{C}$, while interestingly a reaction time longer than $30 \mathrm{~min}$ was required to reach complete oxidation at $350{ }^{\circ} \mathrm{C}$ (Fig. 6c, see also the TGA data in Fig. 2). During the first $5 \mathrm{~min}, \mathrm{O}_{2}$ was not detected in the outlet gas stream of the runs performed at $200{ }^{\circ} \mathrm{C}$ with $21 \mathrm{vol} \% \mathrm{O}_{2}$ and a very small amount of $\mathrm{CO}_{2}$ was detected. This implies that $\mathrm{O}_{2}$ is mainly incorporated into the solid (Fig. 6a). Under those conditions, 15 min was enough time to complete the oxidation process. Complete oxidation reactions producing $\mathrm{CO}_{2}$ took place to a very small extent (Fig. 6a), 


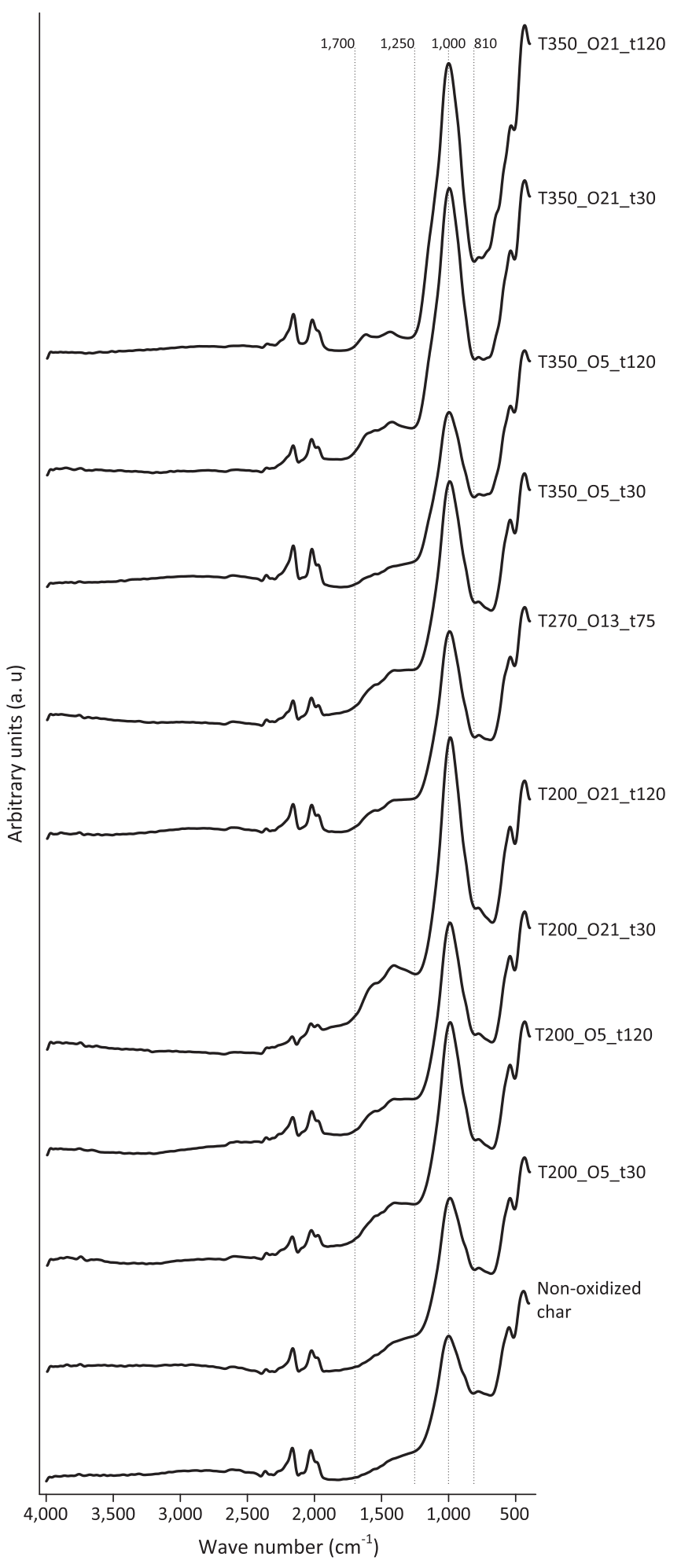

Fig. 4. FTIR spectra of char and oxidized char samples.

which is in agreement with the char yield results reported earlier. $\mathrm{O}_{2}$ was detected in the exiting gas from the beginning of the process for the run performed at $200{ }^{\circ} \mathrm{C}$ with $5 \mathrm{vol} \% \mathrm{O}_{2}$, which shows that only a small fraction of the oxygen reacts under these conditions (Fig. 6a), likely due to kinetics aspects. The presence of $\mathrm{CO}_{2}$ in the exiting gas supports the observed carbon loss under those operational conditions (as revealed by the elemental analyses shown in
Table 5

Carbon and oxygen relative atomic fractions (in \%) and ratio $\mathrm{O}_{\mathrm{s}} / \mathrm{C}_{\mathrm{s}}$ on the char surface.

\begin{tabular}{llll}
\hline Sample ID & $\mathrm{C}_{\mathrm{s}}(\%)$ & $\mathrm{O}_{\mathrm{s}}(\%)$ & $\mathrm{O}_{\mathrm{s}} / \mathrm{C}_{\mathrm{s}}$ \\
\hline Non-oxidized & 73.53 & 17.02 & 0.23 \\
T200_O5_t30 & 64.17 & 23.25 & 0.36 \\
T200_O5_t120 & 60.94 & 25.92 & 0.43 \\
T200_O21_t30 & 59.93 & 26.77 & 0.45 \\
T200_O21_t120 & 59.76 & 27.24 & 0.46 \\
T350_05_t30 & 58.74 & 27.88 & 0.47 \\
T350_05_t120 & 51.99 & 33.50 & 0.64 \\
T350_O21_t30 & 40.81 & 41.90 & 1.03 \\
T350_O21_t120 & 26.86 & 53.20 & 1.98 \\
T275_013_t75 & 57.79 & 29.26 & 0.51 \\
\hline
\end{tabular}

Table 2). $\mathrm{CO}_{2}$ release significantly increased if the oxidation was performed at temperatures higher than $200{ }^{\circ} \mathrm{C}$ (Fig. $6 \mathrm{~b}$ and c). $\mathrm{CO}_{2}$ appeared immediately at the start of the experiment at $350{ }^{\circ} \mathrm{C}$ with $21 \mathrm{vol} \% \mathrm{O}_{2}$ (Fig. 6c), because the high temperature and the highest oxygen concentration promote fast and complete oxidation. The evolution of the concentrations of the carbonaceous gases during the oxidation process is a good indicator of the advance of the oxidation/burn-off reactions. Taking into account that air is a convenient and cheap oxidizing agent, oxidation with air (21 vol \% $\mathrm{O}_{2}$ ) at $200{ }^{\circ} \mathrm{C}$ during 30 min seemed to be the most suitable condition for char activation without being at risk to loose matter through burn-off. Although more severe conditions results in more oxidized char, they also generate char with a higher inorganic fraction. The $\mathrm{O}_{2 \text { carbonlost }} / \mathrm{O}_{2 \text { consumed }}$ percentage ratio was lower than $100 \%$ for all the runs, and increased with the severity of the oxidation conditions (Table 7), meaning that part of the oxygen consumed might be incorporated into the solid or might be removed in the form of $\mathrm{H}_{2} \mathrm{O}$. Even assuming that all the $\mathrm{N}$ and $\mathrm{S}$ missing in the mass balances (Table 3) ended in the form of $\mathrm{NO}_{\mathrm{x}}$ or/ and $\mathrm{SO}_{\mathrm{x}}$ during the oxidation treatment, the quantity of oxygen that would be consumed for their formation would be almost negligible, with the exception of the runs performed at $350{ }^{\circ} \mathrm{C}$ with $21 \% \mathrm{O}_{2}$. The ratio $\mathrm{O}_{2 \text { Carbonlost }} / \mathrm{O}_{2 \text { consumed }}$ was lower for the runs performed at $200{ }^{\circ} \mathrm{C}$, indicating that carbon loss through complete oxidation reactions is not a problem at this temperature.

\subsubsection{Preliminary $\mathrm{NH}_{4}^{+}$adsorption tests}

Beckinghausen et al. (2020) studied the $\mathrm{NH}_{4}^{+}$adsorption of SS char and obtained a capacity of $0.8 \mathrm{mg} \mathrm{NH}_{4}^{+} \mathrm{g}^{-1}$ char. Even with such a low value the authors suggest that utilizing waste materials like SS is an important step towards future sustainable development and circular economy although more research work should be done to determine whether its adsorption capacity can be improved. Preliminary $\mathrm{NH}_{4}^{+}$adsorption tests were performed with both non-oxidized and oxidized chars obtained under selected operating conditions with the objective to test if the increase in the percentage of oxidized carbon on the char surface, as observed in the previously discussed analyses, indeed correlates with an enhanced $\mathrm{SS}_{\text {char }} \mathrm{NH}_{4}^{+}$adsorption capacity.

The $\mathrm{pH}$ of SS char, measured according to the method described in Rajkovich et al. (2012), was 8. This value is adequate for $\mathrm{NH}_{4}^{+}$ adsorption (Yin et al., 2017) and falls within the $\mathrm{pH}$ range for digestate (6.5-8). During the adsorption tests, the $\mathrm{pH}$ remained approximately constant around 7 . $\mathrm{The}^{-} \mathrm{NH}_{4}^{+}$adsorption capacity of SS char varied between 1.2 and $2.2 \mathrm{mg} \mathrm{NH}_{4}^{+} \mathrm{g}^{-1}$ char (Table 8). It appears to correlate with the degree of oxidation, except for the char that was oxidized under the most severe conditions $\left(350{ }^{\circ} \mathrm{C}\right.$, $21 \mathrm{vol} \% \mathrm{O}_{2}$ and $120 \mathrm{~min}$ ). The latter has a $\mathrm{NH}_{4}^{+}$adsorption capacity similar to that of non-oxidized char. The observed improvement in the adsorption capacity are in line with the interpretation that 
Table 6

Relative amount of $C 1$ s species. All data are based on atomic fractions of the specified $C$ s.

\begin{tabular}{|c|c|c|c|c|c|}
\hline Sample ID & $\begin{array}{l}\mathrm{C}-\mathrm{C} ; \mathrm{C}=\mathrm{C} ; \mathrm{C}-\mathrm{H} \\
\text { Peaks } 1+2\end{array}$ & $\begin{array}{l}\mathrm{C}-\mathrm{O} \\
\text { Peak } 3\end{array}$ & $\begin{array}{l}\mathrm{C}=\mathrm{O} ; \mathrm{O}=\mathrm{C}-\mathrm{O} \\
\text { Peak } 4\end{array}$ & $\begin{array}{l}\pi-\pi^{*} \text { satellite } \\
\text { Peak } 5\end{array}$ & Total OFGs \\
\hline Non-oxidized & 60.39 & 27.92 & 6.54 & 5.15 & 34.46 \\
\hline T200_05_t30 & 57.01 & 30.69 & 9.03 & 3.27 & 39.72 \\
\hline T200_O5_t120 & 56.60 & 32.64 & 6.35 & 4.42 & 38.99 \\
\hline T200_021_t30 & 55.96 & 32.44 & 7.78 & 3.82 & 40.22 \\
\hline T200_O21_t120 & 58.63 & 30.65 & 7.22 & 3.50 & 37.87 \\
\hline T350_05_t30 & 54.66 & 32.53 & 8.90 & 3.91 & 41.43 \\
\hline T350_05_t120 & 51.06 & 36.61 & 8.52 & 3.80 & 45.13 \\
\hline T350_021_t30 & 51.14 & 38.23 & 8.41 & 2.22 & 46.63 \\
\hline T350_021_t120 & 47.79 & 44.86 & 7.33 & 0.02 & 52.19 \\
\hline T275_013_t75 & 59.45 & 28.54 & 8.17 & 3.83 & 36.72 \\
\hline
\end{tabular}

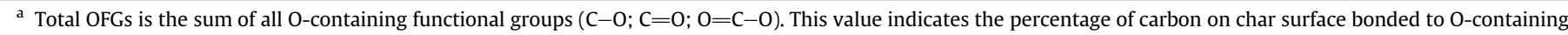
functional groups.

Table 7

$\mathrm{CO}_{2}$ and $\mathrm{CO}$ yields and $\mathrm{O}_{2 \text { Carbonlost }} / \mathrm{O}_{2 \text { consumed }}$ ratio in the fixed bed reactor system.

\begin{tabular}{|c|c|c|c|}
\hline Run ID & $\mathrm{CO}_{2}$ yield (wt. \%) & $\mathrm{CO}$ yield (wt. \%) & $\mathrm{O}_{2 \text { Carbonlost }} / \mathrm{O}_{2 \text { consumed }}(\%)$ \\
\hline T200_05_t30 & 0.5 & 0.0 & 23 \\
\hline T200_O5_t120 & 1.2 & 0.0 & 27 \\
\hline T200_021_t30 & 0.6 & 0.0 & 6 \\
\hline T200_O21_t120 & 1.5 & 0.0 & 19 \\
\hline T350_05_t30 & 3.2 & 0.1 & 34 \\
\hline T350_05_t120 & 24.3 & 1.1 & 65 \\
\hline T350_021_t30 & 19.3 & 1.0 & 48 \\
\hline T350_021_t120 & 62.6 & 2.7 & 74 \\
\hline T275_013_t75 ${ }^{\mathrm{a}}$ & $8.8 \pm 0.6$ & $0.5 \pm 0.2$ & $52 \pm 6$ \\
\hline
\end{tabular}

${ }^{\mathrm{a}}$ Average value \pm standard deviation (3 replicates).

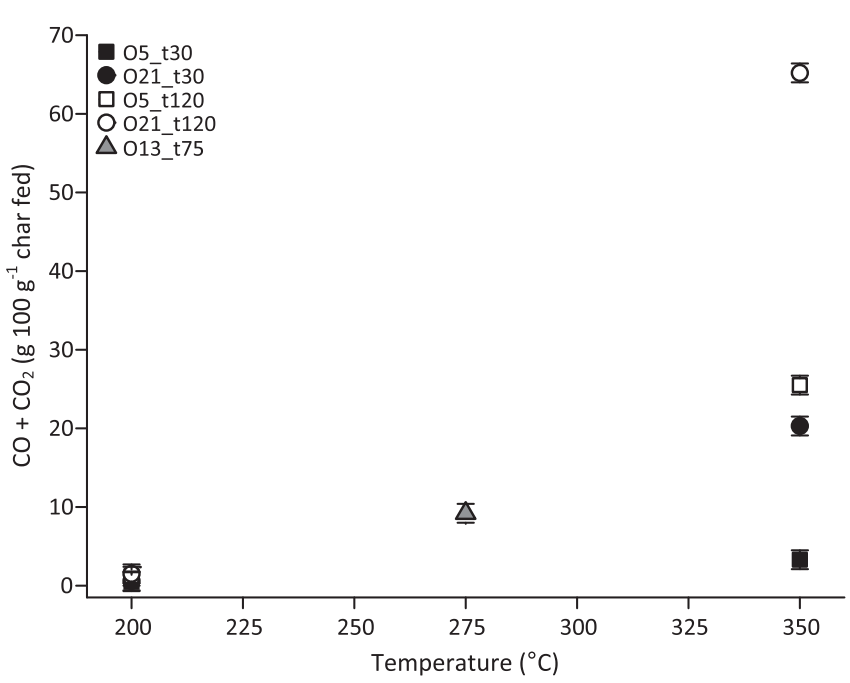

Fig. 5. Gas yield in the fixed-bed reactor system. The results are expressed as the experimental value at each condition \pm 0.5 . Fisher LSD interval (taking into account all the runs) (confidence level $=90 \%$ ).

acidic oxygenated groups were formed on the SS char surface during the oxidation process. At the most severe conditions the oxidation process decreased the total available carbon and the surface area to such an extent that no improvement of the adsorption capacity was achieved. Even though the oxidized char produced at the most severe conditions showed the highest percentage of carbon bonded to oxygen functional groups on char surface, the low bulk carbon content (elemental analysis) and surface area resulted in no increase of the $\mathrm{NH}_{4}^{+}$adsorption capacity. This fact is especially important in wastes such as SS char due to its high ash content. Mild oxidation conditions favored oxygen incorporation into char without significant carbon loss. The highest adsorption capacities were obtained for char oxidized at $200{ }^{\circ} \mathrm{C}$ with air $\left(21 \mathrm{vol} \% \mathrm{O}_{2}\right)$ for $30 \mathrm{~min}$, and for the char oxidized at $350^{\circ} \mathrm{C}$ with $5 \mathrm{vol} \% \mathrm{O}_{2}$ for $30 \mathrm{~min}$. As pointed out by other authors, the specific surface area of char seemed not to be the unique factor for its $\mathrm{NH}_{4}^{+}$adsorption capacity, which means that physisorption would be of minor importance (Yin et al., 2017). Although a more systematic study on $\mathrm{NH}_{4}^{+}$adsorption (repeatability analysis) is required to establish the effect of the operating conditions during the oxidation process on the adsorption capacity of char, the results obtained in this work show that the $\mathrm{NH}_{4}^{+}$adsorption capacity of the SS char can be improved by means of partial oxidation using air as oxidant. Further studies of $\mathrm{NH}_{4}^{\dagger}$ adsorption using oxidized SS char, including the evaluation of the complete isotherms, the desorption studies and the analysis of the effect of $\mathrm{pH}$, temperature and the occurrence of other cations in the waste water on the adsorption capacity are required. The laboratory experimental system used in this work, with $1.5 \mathrm{~g}$ of capacity, is appropriate for studying the effects of partial SS oxidation on char surface properties, but it does not generate enough sample to perform a systematic $\mathrm{NH}_{4}^{+}$ adsorption study. Such a study could be the objective of further work.

Considering the preliminary results obtained in this work, a rough estimation of the amount of the digester side-stream that could be treated by using oxidized SS char, prepared on-site by coupling aerobic digestion and pyrolysis units, can be made. Around $0.8 \mathrm{~kg}$ of digester side-stream and $0.2 \mathrm{~kg}$ of dewatered SS are produced from $1 \mathrm{~kg}$ of digestate (Azuara et al., 2013) in the dewatering procedure. Considering the water content in dewatered SS (around $65 \mathrm{wt} \%$ ) and the char yield in the pyrolysis process, expressed on dry basis ( $55 \mathrm{wt} \%$ ), around $40 \mathrm{~g}$ of char and $0.8 \mathrm{~L}$ of digester side-stream are produced per kg of digestate. Assuming that the average $\mathrm{NH}_{4}^{+}$concentration in digester side-stream is about $1000 \mathrm{mg} \mathrm{L}^{-1}, 800 \mathrm{mg}$ of $\mathrm{NH}_{4}^{+}$need to be removed by the $40 \mathrm{~g}$ of 

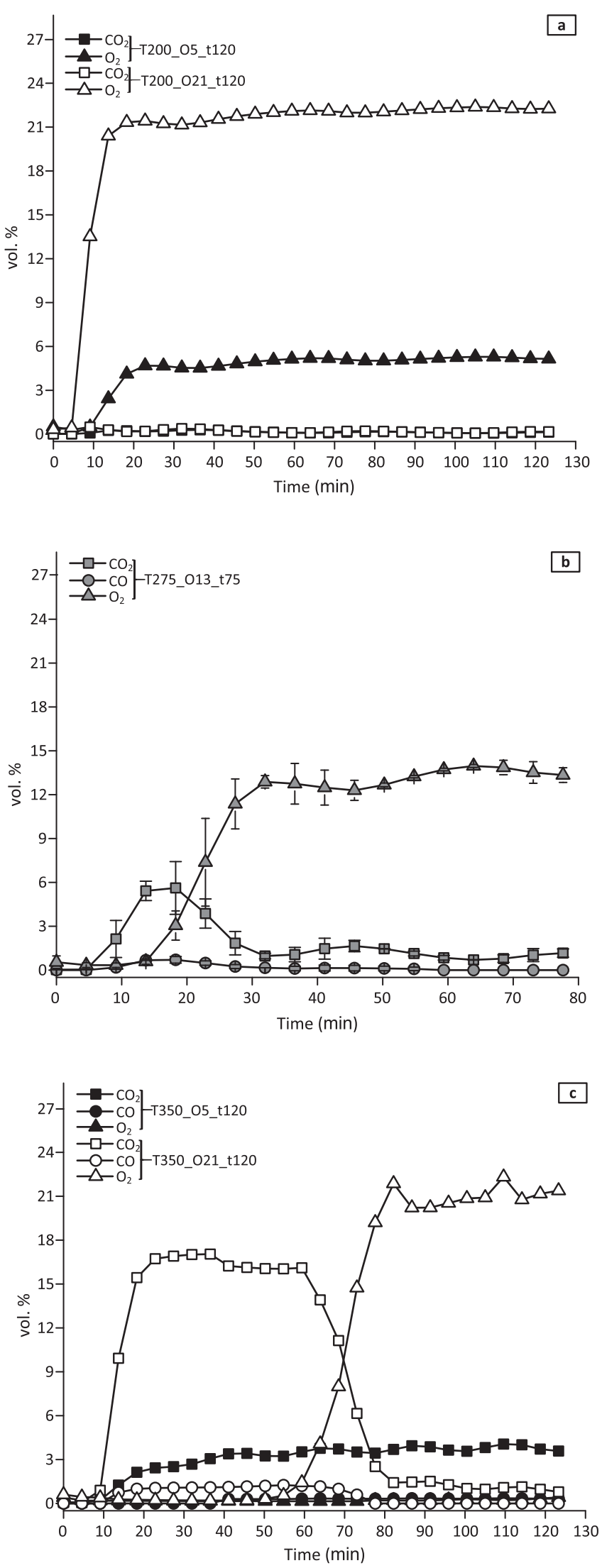

Fig. 6. Temporal evolution $\mathrm{CO}_{2}, \mathrm{CO}$ and $\mathrm{O}_{2}$ concentration during the oxidation process at a) $200{ }^{\circ} \mathrm{C}$ and $\left.30 \mathrm{~min} \mathrm{~b}\right) 275{ }^{\circ} \mathrm{C}$ and $75 \mathrm{~min}$ (averaged from 3 replicates) c) $350{ }^{\circ} \mathrm{C}$ and $120 \mathrm{~min}$.
Table 8

$\mathrm{NH}_{4}^{+}$adsorption capacity.

\begin{tabular}{ll}
\hline Sample ID & $\mathrm{mg} \mathrm{NH}_{4}^{+} \mathrm{g}^{-1}$ char \\
\hline Non-oxidized & 1.2 \\
T200_O5_t30 & 1.6 \\
T200_05_t120 & 1.9 \\
T200_O21_t30 & 2.2 \\
T350_O5_t30 & 2.1 \\
T350_O21_t120 & 1.2 \\
\hline
\end{tabular}

char. The preliminary adsorption results obtained in this work demonstrate that $88 \mathrm{mg}$ can be removed with the best char produced. In other words, about $10 \%$ of the $\mathrm{NH}_{4}^{+}$can be adsorbed using oxidized SS char. The low amount of $\mathrm{NH}_{4}^{+}$uptake suggests that this material cannot directly be used for complete $\mathrm{NH}_{4}^{+}$removal from digester side-stream, but it could be suitable as low cost adsorbent to partially replace commercial adsorbents. Also, the parameter test set is rather sparse and a refinement of those, in particular the oxidation temperature, will likely lead to improved adsorption capacities. Air oxidation at temperatures above $200{ }^{\circ} \mathrm{C}$ but clearly lower than $350^{\circ} \mathrm{C}$ would be a good starting point for the search for $\mathrm{SS}$ char with increased $\mathrm{NH}_{4}^{+}$adsorption capacity. The determination of the optimal conditions is beyond the scope of the current work but could be the goal of a subsequent study.

\section{Conclusions}

Sewage sludge char activation through partial oxidation with air has been studied as a function of oxidation temperature, time and oxygen concentration. All three investigated factors have a significant influence on the content of oxygenated functional groups in oxidized char. Partial oxidation of sewage sludge char using air at $200{ }^{\circ} \mathrm{C}$ or nitrogen-diluted air at $350{ }^{\circ} \mathrm{C}$ are suitable conditions to increase the concentration of oxygenated functional groups on its surface. At the most severe conditions $\left(350{ }^{\circ} \mathrm{C}\right.$ with air) substantial burn-off of the char carbon fraction is observed. Besides carbon, nitrogen and sulfur are also partially oxidized. The textural properties of SS char are hardly affected. $\mathrm{CO}_{2}$ physisorption analysis confirms an increase in the surface area of the carbonaceous fraction, but this increase is counterbalanced by the boost in the char ash fraction caused by partial burn-off.

Based on the current results, oxidative SS char activation at $200{ }^{\circ} \mathrm{C}$ is the most promising method, as it allows to use air as oxidant with very limited char burn-off due to the low temperature. In case of oxidative activation at higher temperatures, the potential occurrence of burn-off needs to be addressed, e.g. in the choice of a proper reactor design. The current data provide guidelines to further optimize this method.

Preliminary $\mathrm{NH}_{4}^{+}$adsorption tests show an improvement in the activated sewage sludge char adsorption capacity by oxidation, but the adsorption capacity is still too low for it to be used as sole adsorbent for complete $\mathrm{NH}_{4}^{+}$removal from the digester sidestream. It could be suitable as a low cost co-adsorbent to partially replace commercial adsorbents. Such a use could present a first step forward towards a circular economy in waste water treatment plants.

\section{CRediT authorship contribution statement}

María Atienza-Martínez: Methodology, Validation, Formal analysis, Data curation, Writing - review \& editing, Visualization. Nurull Nadia Binti Suraini: Formal analysis, Investigation. Javier Ábrego: Data curation, Writing - review \& editing. Isabel Fonts: Data curation, Writing - review \& editing. Luisa Lázaro: 
Investigation. Hans-Heinrich Carstensen: Data curation, Writing review \& editing. Gloria Gea: Conceptualization, Methodology, Validation, Formal analysis, Resources, Data curation, Writing original draft, Writing - review \& editing, Visualization, Supervision, Project administration, Funding acquisition.

\section{Declaration of competing interest}

The authors declare that they have no known competing financial interests or personal relationships that could have appeared to influence the work reported in this paper.

\section{Acknowledgments}

This work was supported by the Aragón Government (Ref. T22_17 R), co-funded by FEDER 2014-2020 "Construyendo Europa desde Aragón", and by MINECO and FEDER (Project CTQ2016-76419-R).

\section{Appendix A. Supplementary data}

Supplementary data to this article can be found online at https://doi.org/10.1016/j.jclepro.2020.125201.

\section{References}

Ábrego, J., Plaza, D., Luño, F., Atienza-Martínez, M., Gea, G., 2018. Pyrolysis of cashew nutshells: characterization of products and energy balance. Energy 158, 72-80. https://doi.org/10.1016/j.energy.2018.06.011.

Alvarez, J., Lopez, G., Amutio, M., Bilbao, J., Olazar, M., 2016. Preparation of adsorbents from sewage sludge pyrolytic char by carbon dioxide activation. Process Saf. Environ. Protect. 103, 76-86. https://doi.org/10.1016/j.psep.2016.06.035.

Anstey, A., Vivekanandhan, S., Rodriguez-Uribe, A., Misra, M., Mohanty, A.K., 2016. Oxidative acid treatment and characterization of new biocarbon from sustainable Miscanthus biomass. Sci. Total Environ. 550, 241-247. https://doi.org/ 10.1016/j.scitotenv.2016.01.015.

Appels, L., Lauwers, J., Degreve, J., Helsen, L., Lievens, B., Willems, K., Van Impe, J., Dewil, R., 2011. Anaerobic digestion in global bio-energy production: potential and research challenges. Renew. Sustain. Energy Rev. 15 (9), 4295-4301. https://doi.org/10.1016/j.rser.2011.07.121.

Azuara, M., Kersten, S.R.A., Kootstra, A.M.J., 2013. Recycling phosphorus by fast pyrolysis of pig manure: concentration and extraction of phosphorus combined with formation of value-added pyrolysis products. Biomass Bioenergy 49, 171-180. https://doi.org/10.1016/j.biombioe.2012.12.010.

Banik, C., Lawrinenko, M., Bakshi, S., Laird, D.A., 2018. Impact of pyrolysis temperature and feedstock on surface charge and functional group chemistry of biochars. J. Environ. Qual. 47 (3), 452-461. https://doi.org/10.2134/jeq2017.11.0432.

Bardestani, R., Kaliaguine, S., 2018. Steam activation and mild air oxidation of vacuum pyrolysis biochar. Biomass Bioenergy 108, 101-112. https://doi.org/ 10.1016/j.biombioe.2017.10.011.

Beckinghausen, A., Reynders, J., Merckel, R., Wu, Y.W., Marais, H., Schwede, S., 2020. Post-pyrolysis treatments of biochars from sewage sludge and A. mearnsii for ammonia $\left(\mathrm{NH}_{4}-\mathrm{n}\right)$ recovery. Appl. Energy 271, 115212. https://doi.org/10.1016/ j.apenergy.2020.115212.

Bougrier, C., Delgenes, J.P., Carrere, H., 2006. Combination of thermal treatments and anaerobic digestion to reduce sewage sludge quantity and improve biogas yield. Process Saf. Environ. Protect. 84 (B4), 280-284. https://doi.org/10.1205/ psep.05162.

Chang, R.H., Sohi, S.P., Jing, F.Q., Liu, Y.Y., Chen, J.W., 2019. A comparative study on biochar properties and $\mathrm{Cd}$ adsorption behavior under effects of ageing processes of leaching, acidification and oxidation. Environ. Pollut. 254, 113123 https://doi.org/10.1016/j.envpol.2019.113123.

De Gisi, S., Lofrano, G., Grassi, M., Notarnicola, M., 2016. Characteristics and adsorption capacities of low-cost sorbents for wastewater treatment: a review. SMT Trends 9, 10-40. https://doi.org/10.1016/j.susmat.2016.06.002.

Demri, B., Muster, D., 1995. XPS study of some calcium compounds. J. Mater. Process. Technol. 55 (3-4), 311-314. https://doi.org/10.1016/0924-0136(95)02023-3.

Estrada, J.M., Kraakman, N.J.R., Lebrero, R., Muñoz, R., 2015. Integral approaches to wastewater treatment plant upgrading for odor prevention: activated Sludge and Oxidized Ammonium Recycling. Bioresour. Technol. 196, 685-693. https:// doi.org/10.1016/j.biortech.2015.08.044.

Figueiredo, J.L., Pereira, M.F.R., Freitas, M.M.A., Orfao, J.J.M., 1999. Modification of the surface chemistry of activated carbons. Carbon 37 (9), 1379-1389. https:// doi.org/10.1016/s0008-6223(98)00333-9.

Fonts, I., Azuara, M., Gea, G., Murillo, M.B., 2009. Study of the pyrolysis liquids obtained from different sewage sludge. J. Anal. Appl. Pyrolysis 85 (1-2), 184-191. https://doi.org/10.1016/j.jaap.2008.11.003.
Grzybek, T., Kreiner, K., 1997. Surface changes in coals after oxidation .1. X-ray photoelectron spectroscopy studies. Langmuir 13 (5), 909-912. https://doi.org/ 10.1021/la9510893.

Hou, J., Huang, L., Yang, Z.M., Zhao, Y.Q., Deng, C.R., Chen, Y.C., Li, X., 2016. Adsorption of ammonium on biochar prepared from giant reed. Environ. Sci. Pollut. Res. 23 (19), 19107-19115. https://doi.org/10.1007/s11356-016-7084-4.

Jassal, R.S., Johnson, M.S., Molodovskaya, M., Black, T.A., Jollymore, A., Sveinson, K., 2015. Nitrogen enrichment potential of biochar in relation to pyrolysis temperature and feedstock quality. J. Environ. Manag. 152, 140-144. https://doi.org/ 10.1016/j.jenvman.2015.01.021.

Jović, V.D., Lacnjevax, U.C., Jović, B.M., 2014. Electrodeposition and characterization of alloys and composite materials. In: Djokić, S.S. (Ed.), Electrodeposition and Surface Finishing: Fundamentals and Applications, pp. 1-84.

Ma, B., Wang, S., Cao, S., Miao, Y., Jia, F., Du, R., Peng, Y., 2016. Biological nitrogen removal from sewage via anammox: recent advances. Bioresour. Technol. 200, 981-990. https://doi.org/10.1016/j.biortech.2015.10.074.

Monsalvo, V., Mohedano, A., Rodriguez, J., 2011. Activated carbons from sewage sludge Application to aqueous-phase adsorption of 4-chlorophenol. Desalination 277 (1-3), 377-382. https://doi.org/10.1016/j.desal.2011.04.059.

Mosallanejad, S., Dlugogorski, B.Z., Kennedy, E.M., Stockenhuber, M., 2017. Adsorption of 2-chlorophenol on the surface of silica- and alumina-supported iron oxide: an FTIR and XPS study. ChemCatChem 9 (3), 481-491. https:// doi.org/10.1002/cctc.201601069.

Ozdemir, E., Duranoglu, D., Beker, U., Avci, A.O., 2011. Process optimization for Cr(VI) adsorption onto activated carbons by experimental design. Chem. Eng. J. 172 (1), 207-218. https://doi.org/10.1016/j.cej.2011.05.091.

Rajkovich, S., Enders, A., Hanley, K., Hyland, C., Zimmerman, A.R., Lehmann, J., 2012. Corn growth and nitrogen nutrition after additions of biochars with varying properties to a temperate soil. Biol. Fertil. Soils 48 (3), 271-284. https://doi.org/ 10.1007/s00374-011-0624-7.

Raymond, C.J., Farmer, J., Dockery, C.R., 2016. Thermogravimetric analysis of target inhibitors for the spontaneous self-heating of coal. Combust. Sci. Technol. 188 (8), 1249-1261. https://doi.org/10.1080/00102202.2016.1177034.

Ruiz-Gómez, N., Quispe, V., Ábrego, J., Atienza-Martínez, M., Murillo, M.B., Gea, G., 2017. Co-pyrolysis of sewage sludge and manure. Waste Manag. 59, 211-221. https://doi.org/10.1016/j.wasman.2016.11.013.

Saha, D., Kienbaum, M.J., 2019. Role of oxygen, nitrogen and sulfur functionalities on the surface of nanoporous carbons in $\mathrm{CO}_{2}$ adsorption: a critical review. Microporous Mesoporous Mater. 287, 29-55. https://doi.org/10.1016/ j.micromeso.2019.05.051.

Sancho, I., Licon, E., Valderrama, C., de Arespacochaga, N., Lopez-Palau, S., Cortina, J.L., 2017. Recovery of ammonia from domestic wastewater effluents as liquid fertilizers by integration of natural zeolites and hollow fibre membrane contactors. Sci. Total Environ. 584, 244-251. https://doi.org/10.1016/ j.scitotenv.2017.01.123.

Sanford, J.R., Larson, R.A., Runge, T., 2019. Nitrate sorption to biochar following chemical oxidation. Sci. Total Environ. 669, 938-947. https://doi.org/10.1016/ j.scitotenv.2019.03.061.

Sarkhot, D.V., Ghezzehei, T.A., Berhe, A.A., 2013. Effectiveness of biochar for sorption of ammonium and phosphate from dairy effluent. J. Environ. Qual. 42 (5), 1545-1554. https://doi.org/10.2134/jeq2012.0482.

Shafeeyan, M.S., Daud, W.M.A.W., Houshmand, A., Shamiri, A., 2010. A review on surface modification of activated carbon for carbon dioxide adsorption. J. Anal. Appl. Pyrolysis 89 (2), 143-151. https://doi.org/10.1016/j.jaap.2010.07.006.

Spokas, K.A., Novak, J.M., Venterea, R.T., 2012. Biochar's role as an alternative Nfertilizer: ammonia capture. Plant Soil 350 (1-2), 35-42. https://doi.org/ 10.1007/s11104-011-0930-8.

Su, H.T., Zhou, F.B., Li, J.S., Qi, H.N., 2017. Effects of oxygen supply on lowtemperature oxidation of coal: a case study of Jurassic coal in Yima, China Fuel 202, 446-454. https://doi.org/10.1016/j.fuel.2017.04.055.

Sujant, W., Zhang, D.K., 2000. Investigation into the role of inherent inorganic matter and additives in low-temperature oxidation of a Victorian brown coal. Combust. Sci. Technol. 152, 99-114. https://doi.org/10.1080/ 00102200008952129.

Suliman, W., Harsh, J.B., Abu-Lail, N.I., Fortuna, A.M., Dallmeyer, I., Garcia-Perez, M., 2016. Modification of biochar surface by air oxidation: role of pyrolysis temperature. Biomass Bioenergy 85, 1-11. https://doi.org/10.1016/ j.biombioe.2015.11.030.

Tangsathitkulchai, C, Ngernyen, Y, Tangsathitkulchai, M., 2009. Surface modification and adsorption of eucalyptus wood-based activated carbons: effects of oxidation treatment, carbon porous structure and activation method. Kor. J. Chem. Eng. 26 (5), 1341-1352. https://doi.org/10.1007/s11814-009-0197-4.

Thermo Scientific X-ray photoelectron spectroscopy, 2013. XPS Spectra Interpretation. xpssimplified.com/index.php. (Accessed 27 January 2020).

Tian, J., Miller, V., Chiu, P.C., Maresca, J.A., Guo, M.X., Imhoff, P.T., 2016. Nutrient release and ammonium sorption by poultry litter and wood biochars in stormwater treatment. Sci. Total Environ. 553, 596-606. https://doi.org/ 10.1016/j.scitotenv.2016.02.129.

Umwelt GmbH, Wehrle, 2016. Eliminación de nitrógeno en retornos de deshidratación de lodos de EDAR. In: Proceso BIOMOX®, SMAGUA-22nd International Water and Irrigation Exhibition, Zaragoza, 8-11 March 2016.

Wang, H.H., Dlugogorski, B.Z., Kennedy, E.M., 2003. Coal oxidation at low temperatures: oxygen consumption, oxidation products, reaction mechanism and kinetic modelling. Prog. Energy Combust. Sci. 29 (6), 487-513. https://doi.org/ 10.1016/s0360-1285(03)00042-X. 
Wang, B., Lehmann, J., Hanley, K., Hestrin, R., Enders, A., 2015. Adsorption and desorption of ammonium by maple wood biochar as a function of oxidation and $\mathrm{pH}$. Chemosphere j.chemosphere.2015.05.062

Wang, B., Lehmann, J., Hanley, K., Hestrin, R., Enders, A., 2016a. Ammonium retention by oxidized biochars produced at different pyrolysis temperatures and residence times. RSC Adv. 6 (48), 41907-41913. https://doi.org/10.1039/ c6ra06419a.

Wang, D.M., Xin, H.H., Qi, X.Y., Dou, G.L., Qi, G.S., Ma, L.Y., 2016b. Reaction pathway of coal oxidation at low temperatures: a model of cyclic chain reactions and kinetic characteristics. Combust. Flame 163, 447-460. https://doi.org/10.1016/ j.combustflame.2015.10.019.

Wójtowicz, M.A., Pels, J.R., Moulijn, J.A., 1995. The fate of nitrogen functionalities in coal during pyrolysis and combustion. Fuel 74 (4), 507-516. https://doi.org/ 10.1016/0016-2361(95)98352-f.

Xiao, F., Bedane, A.H., Zhao, J.X., Mann, M.D., Pignatello, J.., 2018. Thermal air oxidation changes surface and adsorptive properties of black carbon (char/ biochar). Sci. Total Environ. 618, 276-283. https://doi.org/10.1016/ j.scitotenv.2017.11.008.

Yin, Q.Q., Zhang, B.D., Wang, R.K., Zhao, Z.H., 2017. Biochar as an adsorbent for inorganic nitrogen and phosphorus removal from water: a review. Environ. Sci. Pollut. Res. 24 (34), 26297-26309. https://doi.org/10.1007/s11356-017-0338-y. Youness, R.A., Taha, M.A., Ibrahim, M., El-Kheshen, A., 2018. FTIR spectral characterization, mechanical properties and antimicrobial properties of La-doped phosphate-based bioactive glasses. Silicon 10 (3), 1151-1159. https://doi.org/ 10.1007/s12633-017-9587-0.

Zhan, J., Wang, H., Zhu, F., Song, S., 2014. Analysis on the governing reactions in coa oxidation at temperatures up to $400{ }^{\circ} \mathrm{C}$. IJCCE 3 (2), 19-28. https://doi.org/ 10.4236/ijcce.2014.32003.

Zhang, J.S., Wang, Q.Q., 2016. Sustainable mechanisms of biochar derived from brewers' spent grain and sewage sludge for ammonia-nitrogen capture. J. Clean. Prod. 112, 3927-3934. https://doi.org/10.1016/j.jclepro.2015.07.096.

Zhang, Y., Li, Z.F., Mahmood, I.B., 2014. Recovery of $\mathrm{NH}_{4}^{+}$by corn cob produced biochars and its potential application as soil conditioner. Front. Environ. Sci. Eng. 8 (6), 825-834. https://doi.org/10.1007/s11783-014-0682-9. 